\title{
A Socio-Hydrological Perspective on Recent and Future Precipitation Changes Over Tropical Montane Cloud Forests in the Andes
}

\author{
Fausto O. Sarmiento* and Gabriel J. Kooperman \\ Neotropical Montology Collaboratory and Climate, Clouds and Land Modeling Group, Department of Geography, University \\ of Georgia, Athens, GA, United States
}

Keywords: tropical montane cloud forests, precipitation change, socio-hydrology, Tropandean landscapes, earth system models, climate change

OPEN ACCESS

Edited by:

Alfonso Fernandez,

Universidad de Concepción, Chile

Reviewed by:

Vernon Scarborough

University of Cincinnati, United States Jeff La Frenierre,

Gustavus Adolphus College,

United States

*Correspondence:

Fausto O. Sarmiento

fsarmien@uga.edu

Specialty section:

This article was submitted to

Atmospheric Science,

a section of the journal

Frontiers in Earth Science

Received: 09 September 2019 Accepted: 21 November 2019

Published: 10 December 2019

Citation:

Sarmiento FO and Kooperman GJ

(2019) A Socio-Hydrological

Perspective on Recent and Future

Precipitation Changes Over Tropical Montane Cloud Forests in the Andes.

Front. Earth Sci. 7:324.

doi: 10.3389/feart.2019.00324
Tropical montane cloud forests (TMCFs) in the Andes, with mild temperatures and plenty of water, boast prodigious biocultural diversity. Runoff from these slopes supports local communities by supplying drinking water and irrigation to growing lowland cities. However, precipitation in the region is sensitive to human environmental impacts and effective conservation planning requires assessing past and future climate changes in local cultural, historical, and political contexts. In particular, Earth System Models (ESMs) suggest a reduction in precipitation over most tropical land, including TMCFs in the Andes during the twentieth century, has been driven largely by increases in aerosol emissions (Wang, 2015). With the exception of the Amazon rainforest, this trend reverses in the twenty first century, with increases in precipitation over Asia, Central Africa, and the tropical Andes, as greenhouse gas-driven changes become the dominant response (Stocker et al., 2013; Kooperman et al., 2018a). Although multi-model mean changes are large, many ESMs show opposing trends on regional scales, and historical observations are limited, leading to uncertainties for past and future changes.

Focusing on TMCFs in the Andes, we survey how this reversal of precipitation change in the twenty first century, and its associated uncertainties, may impact the complex interplay of cultural ecosystem services (CES) that TMCFs provide. We seek to highlight the need for transdisciplinary perspectives to understand how recent and future precipitation changes interact with the socioecological systems of Tropandean mountainscapes. We present results from widely-used climate models, which have contributed to the Coupled Model Intercomparison Project Phase Five (CMIP5, Taylor et al., 2012), to highlight the large but uncertain changes in this region. We then assess single forcing experiments, provided by the Community Earth System Model (CESM1) Large Ensemble project (Hurrell et al., 2013; Kay et al., 2015), to identify the anthropogenic drivers of precipitation change over the Andes. These results serve to illustrate a global modeling perspective and communicate the need to consider local CES in the development of effective adaptation measures. We argue that understanding societal implications of climate change on TMCF hydroclimates should include past and future considerations of the socio-hydrological dimension as well as the physical climate.

In this opinion, we discuss the historic role of fire in cultural practices, the influence of present-day biomass burning aerosol on precipitation, future drivers of precipitation change and local water resource use, to highlight the need for new research at the intersection of these areas.

\section{TROPANDEAN ECOREGION}

Neotropical landscapes harbor globally important hotspots of biodiversity (Myers, 2003; Lovejoy and Hanna, 2019) and bolster ancestral cultures that have developed a manufactured landscape 
(White, 2013; Scarborough et al., 2019) depending on rain water for irrigation and dry-slope agriculture. To illustrate the complexity of socio-hydrological coupling and change in mountainous areas with humans dating back thousands of years, we selected the Tropandean region of Central America and Northern South America. The equatorial mountains of the Andean crescent (Chinchaysuyu), reportedly the wettest part of the planet (Bush, 2002), exhibit the largest number of species per unit area in any terrestrial ecosystem, with predominant taxa including birds, reptiles, amphibians, and insects. This is also the place where most bryophytes are found, along with the largest diversity of broad-leaf species, mainly Lauracea and Areacacea families. In recent history, the landscape has been transformed by the pressures of modernity (e.g., monoculture, urbanization, invasive species, and biodiversity loss) and exhibits significant climate changes in historic and future ESM simulations (Stocker et al., 2013). But the influence of humans on the local mountainscape dates back much further-indigenous cultures have domesticated cloud forests and opened highland terrains of this region for hunting, gathering, planting, livestock rearing, and other more consumptive activities such as mining and handcrafting metals and fibers. Many of these activities involve the use of fire, the most important tool for Andean treeline ecotone region (ATER) transformation (Sarmiento and Frolich, 2002), which has reshaped local mountainscapes over centuries.

The long history of fire use in TMCFs is evident in records of charcoal cairns and in the generalized management to maintain and expand grasslands in the mountains (Luteyn and Balslev, 1992). This explains the mythology associated with burning and its connection with rain-in the Andean pantheon, fire has been used to placate the gods' wrath with their dry spell, and to bring back the rains to restore mountain harmony (Urku kawsay) (Steele and Allen, 2004). Inka mythology identifies the supreme deity Wirakucha who brought winds and rains to the mountains (Urton, 1999). Andean cultures follow practices of respect and reciprocity (Ayni) to promote a balanced subsistence for people, animals, plants, and mountains (Sumak kawsay). Thus, culturally appropriate to the Andean philosophy, burning of highland grasslands (or paramo) and TCMFs are daily occurrences in ATERs (CarrilloRojas et al., 2019; Knapp, 2019) producing heavy loads of atmospheric black carbon in the soils. At the same time, aerosol emissions from biomass burning can be pernicious sources of air pollution, with significant impacts on human health (Reddington et al., 2015). These emissions can be transported over long distances (Bourgeois et al., 2015) and impact remote ecosystems (Boy et al., 2008). Aerosol also influences the climate by modifying the atmospheric thermodynamic state and circulation patterns (Thornhill et al., 2018), as well as cloud microphysical properties, all of which can modulate precipitation patterns (Tao et al., 2012).

Precipitation is critical to the maintenance of CES and the overall availability of freshwater, which incorporate the intangibles to mountainscape (Urkumanta) conservation (Sarmiento, 2016). However, regional precipitation changes are driven by not only local pyroecology influences on the environment, but also non-local influences, such as biomass burning aerosol from the Amazon and global-scale climate change (Stocker et al., 2013). Additionally, it is challenging for conservation planning to bring ESM scale projections into the context of local cultural, historical, and political perspectives. Particularly in the tropical Andes, where large future changes in precipitation are projected (Figure 1B), but with significant uncertainty, in part because the fine-scale topographic features of the region are not resolved in globalscale models. Progress toward understanding regional climate changes and impacts thus requires ecological modeling across global to local scales, including paleoecological parameters in hindcasting and forecasting extreme scenarios of change (Cheddadi et al., 2019), and taking into account historical socioecological perspectives.

Below we separately present global modeling and political ecological perspectives in order to emphasize the need for research that connects across these disparate scales and disciplines.

\section{GLOBAL MODELING PERSPECTIVE}

Over the last decade, global climate models have evolved into fully capable representations of the Earth system, including interactive treatments of the atmosphere, ocean, land, and sea-ice. The atmospheric component of many ESMs includes aerosol particles that are advected from source regions and can influence cloud droplet number, radiative properties of the atmosphere and precipitation (Neale et al., 2010). The land component includes a variety of plant types with physiological properties that depend on temperature, moisture and $\mathrm{CO}_{2}$ concentration (Lawrence et al., 2011). All of these processes are critical for capturing the complex coupled responses that govern changes in precipitation over the Andes, which undoubtedly will affect the distribution, community composition and structure of TMCFs in the Andean crescent.

The CMIP5 multi-model mean precipitation change over the twentieth century, from a subset of advanced models in which aerosol concentrations directly affect cloud droplet formation (i.e., CanESM2, von Salzen et al., 2013; CESM1-CAM5, Hurrell et al., 2013; CSIRO-Mk3-6-0, Rotstayn et al., 2012; GFDL-CM3, Donner et al., 2011; HadGEM2-ES, Martin et al., 2011; MIROCESM-CHEM, Watanabe et al., 2011; MIROC-ESM, Watanabe et al., 2011; MRI-CGCM3, Yukimoto et al., 2012; NorESM1M, Iversen et al., 2013; FGOALS-g2, Li et al., 2013), shows drying across the tropics, particularly over Asia, northern South America, and Central America (Figure 1A). This pattern emerges even in simulations without changes in greenhouse gases and is linked instead to anthropogenic aerosol emissions (Wang, 2015). In a set of single forcing experiments, which isolate the contribution from different anthropogenic forcing agents (e.g., greenhouse gases, aerosol from industry and transportation, aerosol from biomass burning, and land-cover change), we find the historical drying pattern in CESM1 over the equatorial Andes (and Indonesia) results primarily from biomass burning aerosol emissions (Figures 1C-G). 


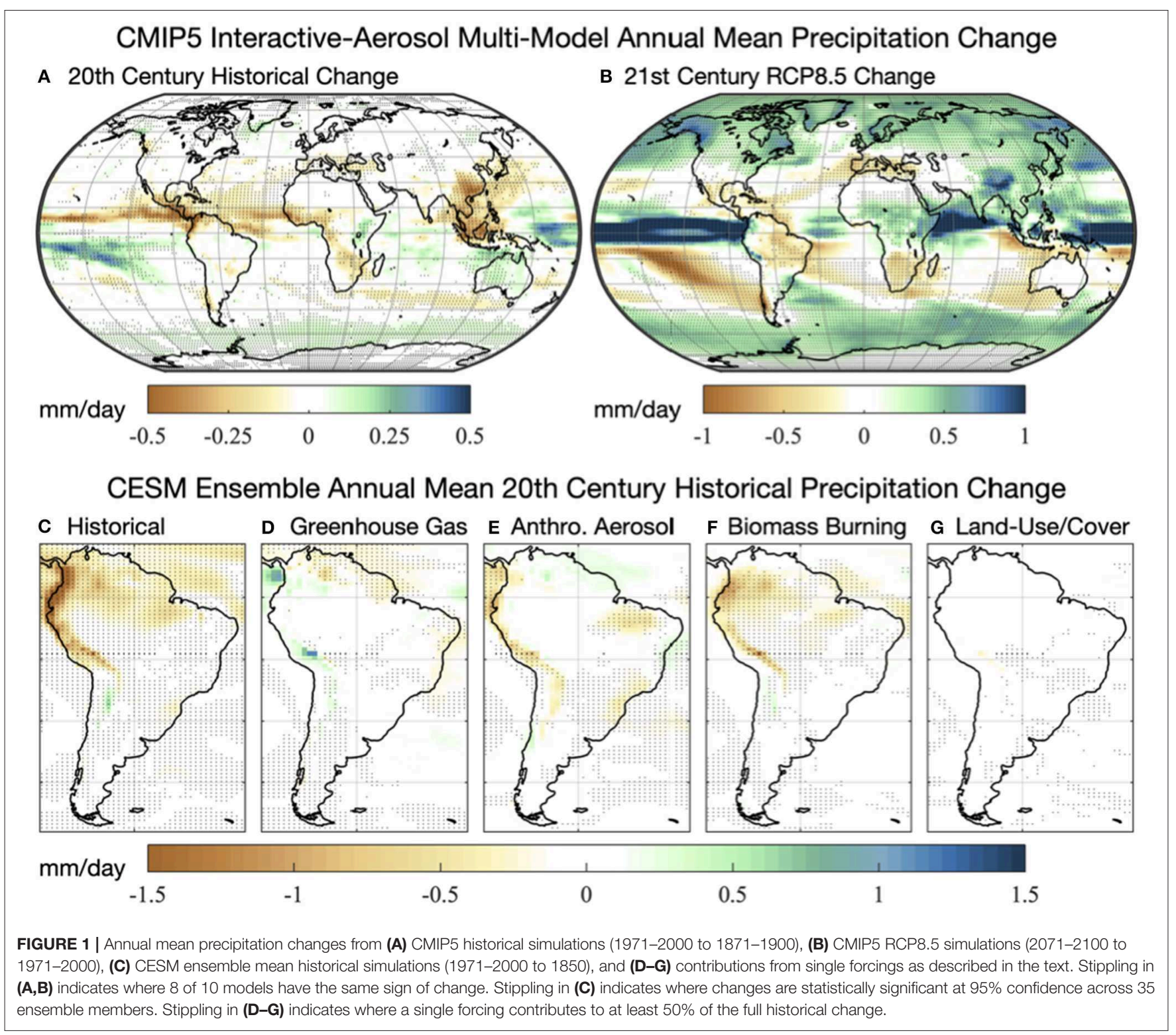

In the twenty first century, under the Representative Concentration Pathway 8.5 scenario, the same set of CMIP5 models show that this signal reverses over most tropical land, leading to increases over Asia, Central Africa, and the Andes (Figure 1B). Future changes over South America include a decrease over the Amazon and an increase over the Andes, which has been associated with both an atmospheric-radiative response to higher greenhouse gases and a plant-physiological response to higher $\mathrm{CO}_{2}$ concentrations (i.e., reduced stomatal conductance and transpiration) (Figure 1 from Kooperman et al., 2018a). The plant-physiological response leads to suppressed convection over the Amazon forest and circulation pathways that enhance moisture flow up the eastern slopes of the Andes (Langenbrunner et al., 2019). Reductions in transpiration due to plant responses to higher $\mathrm{CO}_{2}$ also leave more moisture in the soil column, which can contribute to increases runoff and flooding in the Andes (Kooperman et al., 2018b).

These ESM results reveal a reversing trend in precipitation changes over the equatorial Andes from the twentieth to twenty first centuries. Historical simulations, and indigenous knowledge, suggest that fires have played an important role in the climate of Andes over the last hundred and thousands of years, respectively. As Amazon fires continue in the presentday, the long ranging impacts of their emissions are likely to remain a strong influence on the near-term climate of the Andes. But as the concentrations of greenhouse gases rise, global-scale warming and circulation changes may drive an opposing response that increases precipitation. However, despite the large magnitude of change in the multi-model mean, many individual models can disagree on the sign of 
the change (i.e., lack of stippling in Figures 1A,B). These competing drivers of environmental change and uncertainty across model simulations in the region, in combination with local socio-cultural pressures, present a major challenge for conservation efforts.

\section{POLITICAL ECOLOGICAL PERSPECTIVE}

As dynamic constructs, press and pulse disturbances drive change in the socio-ecological landscapes of the Tropical Andes, which continues to ignite scholarly debate on whether forests or grasslands (Appenzeller, 2019). Amidst ancestral customary law and ritualized practices in relation to mountain fires, political decisions on resource use and nature conservation have overlooked the anthropogenic proxy for climate and landuse transformation (Chepstow-Lusty et al., 1996; Varela, 2008; Sarmiento, 2012). Historical accounts and other geocritical literature have been used to develop a critical discourse analysis of water-fire interactions (Garreaud, 2007; Sarmiento et al., 2019), but difficulties remain in bringing together multimethod approaches for the study of deforestation (Delabre et al., 2019). Of special note is the extensive impact of colonial timber use for construction and heating in growing Andean cities. Much of the regional deforestation has been driven by procuring cheap fuelwood and charcoal. In fact, charcoal production and commercialization became the most important activity of a growing domestic energy source (Wunder, 1996) often associated with impoverished populations (Garofalo, 2019).

Old approaches, favoring exotic plantations, increasing the agricultural frontier and establishing payments for ecosystem services, are beginning to shift toward new considerations of CES. These include reforestation with native species, agroecological practices, community-based conservation, and nature benefits to people, with value of spirituality, myths, traditions, and landscape memory of decolonial thinking of the sacred transition (Sarmiento et al., 2017; Oslender, 2019). This is a transitional phase where the multiple values of nature approach incorporates factors of local cosmological views as well as the intangibles (i.e., heirloom flavors, textile designs, rituals) and incommensurables (i.e., national identity, rootedness, spirituality) of CES (Alimonda, 2016). Most conservation programs from either governments or NGOs are required to include social science into the fabric of research for climate effects and sustainability, as Rousseau's (2017) manifesto claiming for transdisciplinary understanding of Earth systems. The political ecology of ice and water in the Andes remains an academic concern to secure climate adaptation measures (Nüsser, 2017; Hock et al., 2019) and adequate representation of mountain development priorities (Sarmiento, 2016).

Because of the shifting paradigm of decolonial histories, a new transdisciplinary effort is needed to fully grasp the waterclimate conundrum (Fonstead, 2017). We must understand not only the changes to the physical climate system (e.g., observing and simulating river flow and discharge, horizontal precipitation, glacial mass, and snow pack), but develop a holistic portrait of environmental-societal interactions and impacts (Sarmiento, 2008) for a more comprehensive view of future adaptations to climate change in the ATER.

\section{CONCLUSION}

We emphasize that epistemes of climate changes in TMCFs of the Tropandean landscapes may only be reached by bridging the gap across the scales of ESM to the socio-hydrological tenants of a local community's perceptions. In the short-term climate, the ATER may continue to be strongly influenced by remote biomass burning emissions and forest fires at the fringes. In the long-term climate, a trend of increasing precipitation over the twenty first century due to rising $\mathrm{CO}_{2}$ and global warming, may affect people of Andean communities with future impacts on water management and overflow control, landslide and rockslide (Wayku) management, and flooding. Coupled modeling of the past and future co-dependency of physical and human geographies in the mountainscape is needed to reduce uncertainty in the application of adaptation measures toward resilient, sustainable futures.

\section{AUTHOR CONTRIBUTIONS}

FS and GK both contributed to writing and editing the manuscript. FS contributed specifically to the political ecological section. GK contributed to the global modeling section.

\section{ACKNOWLEDGMENTS}

We acknowledge the World Climate Research Programme's Working Group on Coupled Modeling for CMIP5, and the climate modeling groups referenced in the manuscript for producing and making available their model output. For CMIP5 the U.S. Department of Energy's Program for Climate Model Diagnosis and Intercomparison provides coordinating support and led development of software infrastructure in partnership with the Global Organization for Earth System Science Portals. CESM development is led by the National Center for Atmospheric Research (NCAR) with support from the U.S. National Science Foundation and U.S. Department of Energy. Computing resources for the CESM Large Ensemble Community Project were provided on Yellowstone by NCAR Computational Information Systems Laboratory. GK acknowledges support from the U.S. Department of Energy Regional and Global Model Analysis (RGMA) Program (DE-SC0019459) as well as the University of Georgia's Office of Research, Junior Faculty Seed Grant Program and President's Interdisciplinary Seed Grant Program. FS acknowledges support from the U.S. National Science Foundation (NSF) counterpart funding to the Belmont Forum for Mountains (BF) on Vulnerability of Populations Under Extreme Scenarios (VULPES) grant (ANR-15-MASC0003) as well as the UGA's Office of Research/Office of International Education Global Collaborative Research Program. We also thank the editors of this Special Issue and two reviewers who enhanced the manuscript. 


\section{REFERENCES}

Alimonda, H. (2016). Notas sobre la ecología política latinoamericana: arraigo, herencias, diálogos. Ecol. Polít. 51, 36-42.

Appenzeller, T. (2019). Fire on the mountain. Science 365, 1094-1097. doi: 10.1126/science.365.6458.1094

Bourgeois, Q., Ekman, A. M. L., and Krejci, R. (2015). Aerosol transport over the Andes from the Amazon Basin to the remote Pacific Ocean: a multiyear CALIOP assessment. J. Geophys. Res. Atmos. 120, 8411-8425. doi: 10.1002/2015JD023254

Boy, J., Rollenbeck, R., Valarezo, C., and Wilcke, W. (2008). Amazonian biomass burning-derived acid and nutrient deposition in the north Andean montane forest of Ecuador. Global Biogeochem. Cy. 22:GB4011. doi: 10.1029/2007GB003158

Bush, M. B. (2002). Distributional change and conservation on the Andean flank: a palaeoecological perspective. Glob. Ecol. Biogeogr. 11, 463-473. doi: 10.1046/j.1466-822X.2002.00305.x

Carrillo-Rojas, G., Silva, B., Rollenbeck, R., Célleri, R., and Bendix, J. (2019). The breathing of the Andean highlands: net ecosystem exchange and evapotranspiration over the páramo of southern Ecuador. Agri. Forest Meteorol. 265, 30-47. doi: 10.1016/j.agrformet.2018.11.006

Cheddadi, R., Mahammdi, M., and Sarmiento, F. O. (2019). Past plant diversity changes and mountain tree species conservation. Past Global Change. Mag. 27:36. doi: 10.22498/pages.27.1.36

Chepstow-Lusty, A. J., Bennett, K. D., Switsur, V. R., and Kendall, A. (1996). 4000 years of human impact and vegetation change in the Central Peruvian Andes-with events parallelling the Maya record? Antiquity 70, 824-833. doi: 10.1017/S0003598X0008409X

Delabre, I., Alexander, A., Rowhani, P., and Antonarakis, A. (2019). "Politics and power in managing data on zero deforestation: lessons and challenges for integrating multi-disciplinary natural and social science methods," in American Association of Geographers Annual Meeting (Washington, DC).

Donner, L. J., Wymana, B. L., Hemlera, R. S., Horowitza, L. W., Minga, Y., Zhao, M., et al. (2011). The dynamical core, physical parameterizations, and basic simulation characteristics of the atmospheric component AM3 of the GFDL Global Coupled Model CM3. J. Clim. 24, 3484-3519. doi: 10.1175/2011JCLI3955.1

Fonstead, M. (2017). Mountains: Physical, Human-Environmental and SocioCultural Dynamics. New York, NY: Routledge.

Garofalo, L. (2019). "Black space production in Andean societies," in Chapter 16: Transnational Perspectives on the Conquest and Colonization of Latin America, eds J. Mander, D. Midgley, and C. Beaule (Abingdon: Routledge). doi: 10.4324/9780429330612-17

Garreaud, R. (2007). The Andes climate and weather. Adv. Geosci. 22, 3-11. doi: 10.5194/adgeo-22-3-2009

Hock, R. G., Rasul, C., Adler, B., Cáceres, S., Gruber, Y., Hirabayashi, M., et al. (2019). "Chapter 2: High mountain areas," in IPCC SR Ocean and Cryosphere Report (MRI Mountain Research Initiative).

Hurrell, J., Holland, M. M., and Gent, P. R. (2013). The community earth system model: a framework for collaborative research. Bull. Am. Meteorol. Soc. 94, 1339-1360. doi: 10.1175/BAMS-D-12-00121.1

Iversen, T., Bentsen, M., Bethke, I., Debernard, J. B., Kirkevåg, A.,Seland, O., et al. (2013). The Norwegian earth system model, NorESM1-M. Part 2: climate response and scenario projections. Geosci. Model Dev. 6, 1-27. doi: 10.5194/gmd-6-389-2013

Kay, J. E., Deser, C., Phillips, A., Mai, A., Hannay, C., Strand, G., et al. (2015). The Community Earth System Model (CESM) large ensemble project: a community resource for studying climate change in the presence of internal climate variability. Bull. Amer. Meteor. Soc. 96, 1333-1349. doi: 10.1175/BAMS-D-13-00255.1

Knapp, G. (2019). Andean Ecology: Adaptive Dynamics in Ecuador. Nashville, TN: Routledge. doi: 10.4324/9780429046186

Kooperman, G. J., Chen, Y., Hoffman, F. M., Koven, C. D., Lindsay, K., Pritchard, M. S., et al. (2018a). Forest response to rising $\mathrm{CO}_{2}$ drives zonally asymmetric rainfall change over tropical land. Nat. Clim. Change 8, 434-440. doi: 10.1038/s41558-018-0144-7

Kooperman, G. J., Fowler, M. D., Hoffman, F. M., Koven, C. D., Lindsay, K., Pritchard, M. S., et al. (2018b). Plant physiological responses to rising $\mathrm{CO}_{2}$ modify simulated daily runoff intensity with implications for global-scale flood risk assessment. Geophys. Res. Lett. 45, 12457-12466. doi: 10.1029/2018GL079901

Langenbrunner, B., Pritchard, M. S., Kooperman, G. J., and Randerson, J. T. (2019). Why does Amazon precipitation decrease when tropical forests respond to increasing $\mathrm{CO}_{2}$ ? Earths Fut. 7, 450-468. doi: 10.1029/2018EF 001026

Lawrence, D. M., Oleson, K. W., Flanner, M. G., Thornton, P. E., Swenson, S. C., Lawrence, P. J., et al. (2011). Parameterization improvements and functional and structural advances in version 4 of the community land model. J. $A d v$. Model. Earth Syst. 3:M03001. doi: 10.1029/2011MS00045

Li, L., Wang, B., Dong, L., Liu, L.,Shen, S., Hu, N., et al. (2013). Evaluation of gridpoint atmospheric model of IAP LASG version 2 (GAMIL2). Adv. Atmos. Sci. 30, 855-867. doi: 10.1007/s00376-013-2157-5

Lovejoy, J., and Hanna, L. (eds.). (2019). Climate Change and Biodiversity. New Haven, CT: Yale University Press.

Luteyn, J. L., and Balslev, H. (eds.). (1992). Páramo: An Andean Ecosystem Under Human Influence. London: Academic Press.

Martin, G. M., Bellouin, N., Collins, W. J., Culverwell, I. D., Halloran, P. R., Hardiman, S. C., et al. (2011), The HadGEM2 family of met office unified model climate configurations. Geophys. Model Dev. 4, 723-757. doi: 10.5194/gmd-4-723-2011

Myers, N. (2003). Biodiversity hotspots revisited. BioScience 53, 916-917. doi: 10. 1641/0006-3568(2003)053[0916:BHR]2.0.CO;2

Neale, R. B., Gettelman, A., Park, S., Conley, A. J., Kinnison. D., Marsh. D., et al. (2010). NCAR Technical Note: Description of the NCAR Community Atmosphere Model (CAM 5.0). National Center for Atmospheric Research, Boulder, CO, United States.

Nüsser, M. (2017). Socio-hydrology: a new perspective on mountain waterscapes at the nexus of natural and social processes. Mt. Res. Dev. 37, 518-520. doi: 10.1659/MRD-JOURNAL-D-17-00101.1

Oslender, U. (2019). Geographies of the pluriverse: decolonial thinking and ontological conflict on Colombia’s Pacific Coast. Ann. Am. Assoc. Geogr. 109, 1691-1705. doi: 10.1080/24694452.2019.1572491

Reddington, C. L., Butt, E. W., Ridley, D. A., Artaxo, P., Morgan, W. T., Coe, H., et al. (2015). Air quality and human health improvements from reductions in deforestation-related fire in Brazil. Nat. Geosci. 8, 768-771. doi: 10.1038/ngeo2535

Rotstayn, L. D., Jeffrey, S. J., Collier, M. A., Dravitzki, S. M., Hirst, A. C., Syktus, J. I., et al. (2012). Aerosol- and greenhouse gas-induced changes in summer rainfall and circulation in the Australasian region: a study using single-forcing climate simulations. Atmos. Chem. Phys. 12, 6377-6404. doi: 10.5194/acp-12-6377-2012

Rousseau, D. (2017). "February. manifesto for General Systems Transdisciplinarity (GSTD)," in Proceedings of the 59th Annual Meeting of the ISSS-2015 (Berlin).

Sarmiento, F. O. (2008). Andes mountains and human dimensions of global change: an overview. Pirineos Rev. Ecol. Mont. 163, 7-13. doi: 10.3989/pirineos.2008.v163.18

Sarmiento, F. O. (2012). Contesting Páramo: Critical Biogeography of the Northern Andean Highlands. Charlotte, NC: Kona Publishing. Higher Education Division.

Sarmiento, F. O. (2016). "Neotropical mountains beyond water supply: environmental services as a trifecta of sustainable mountain development," in Mountain Ice and Water: Investigations of the Hydrologic Cycle in Alpine Environments, eds G. Greenwood and J. Shroder (New York, NY: Elsevier), 309-324. doi: 10.1016/B978-0-444-63787-1.00008-1

Sarmiento, F. O., and Frolich, L. M. (2002). Andean cloud forest tree lines. Mt. Res. Dev. 22, 278-288. doi: 10.1659/0276-4741(2002)022[0278:ACFTL]2.0.CO;2

Sarmiento, F. O., González, J. A., Lavilla, E. O., Donoso-Correa, M. E., and Ibarra, J. T. (2019). Onomastic misnomers in the construction of faulty andeanity and weak andeaness: biocoultural refugia in the Andes. Pirineos. Rev. Ecol. Mont. 174, 1-16. doi: 10.3989/pirineos.2019.174009

Sarmiento, F. O., Ibarra, J. T., Barreau, A., Pizarro, J. C., Rozzi, R., González, J. A., et al. (2017). Applied montology using critical biogeography in the Andes. Ann. Am. Assoc. Geogr. 107, 416-428. doi: 10.1080/24694452.2016.1260438

Scarborough, V. L., Isendahl, C., and Fladd, S. (2019). "Environment and landscapes of Latin America's past," in Global Perspectives on Long Term Community Resource Management, eds L. Lozny, T. 
McGovern, H. Thomas, and R. Ludomir (Berlin: Springer), 213-234. doi: 10.1007/978-3-030-15800-2_10

Steele, P. R., and Allen, C. J. (2004). Handbook of Inca Mythology. Santa Barbara, CA: abc-clio.

Stocker, T. F. D., Qin, G. K., Tignor, P. M., Allen, S. K., Boschung, J., Nauels, A., et al. (2013). Climate Change 2013: The Physical Science Basis. Contribution of Working Group I to the Fifth Assessment Report of the Intergovernmental Panel on Climate Change. Cambridge: Cambridge University Press.

Tao, W. K., Chen, J. P., Li, Z., Wang, C., and Zhang, C. (2012). Impact of aerosols on convective clouds and precipitation. Rev. Geophys. 50:RG2001. doi: 10.1029/2011RG000369

Taylor, K. E., Stouffer, R. J., and Meehl G. A. (2012). An overview of CMIP5 and the experiment design. Bull. Amer. Meteor. Soc. 93, 485-498. doi: 10.1175/BAMS-D-11-00094.1

Thornhill, G. D., Ryder, C. L., Highwood, E. J., Shaffrey, L. C., and Johnson, B. T. (2018). The effect of South American biomass burning aerosol emissions on the regional climate. Atmos. Chem. Phys. 18, 5321-5342. doi: 10.5194/acp-18-5321-2018

Urton, G. (1999). Inca Myths. Austin, TX: University of Texas Press.

Varela, L. (2008). La alta montaña del norte de los andes: el páramo, un ecosistema antropogénico. Pirineos. Rev. Ecol. Mont. 163, 85-95. doi: 10.3989/pirineos.2008.v163.24

von Salzen, K., Scinocca, J. F., McFarlane, N. A., Li, J., Cole, J. N. S., Plummer, D., et al. (2013). The Canadian fourth generation atmospheric global climate model (CanAM4). Part I: representation of physical processes. Atmos. Ocean. 51, 104-125. doi: 10.1080/07055900.2012.755610
Wang, C. (2015). Anthropogenic aerosols and the distribution of past large-scale precipitation change. Geophys. Res. Lett. 42, 10876-10884. doi: 10.1002/2015GL066416

Watanabe, M., Chikira, M., Imada, Y., and Kimoto, M. (2011). Convective control of ENSO simulated in MIROC. J. Clim. 24, 543-562. doi: $10.1175 / 2010 J C L I 3878.1$

White, S. (2013). Grass páramo as hunter-gatherer landscape. Holocene 23, 898-915. doi: 10.1177/0959683612471987

Wunder, S. (1996). Deforestation and the uses of wood in the Ecuadorian Andes. Mt. Res. Dev. 16, 367-381. doi: 10.2307/3673987

Yukimoto, S., Adachi, Y., Hosaka, M., Sakami, T., Yoshimura, H., Hirabara, M. et al. (2012). A new global climate model of the Meteorological Research Institute: MRI-CGCM3-Model description and basic performance. J. Meteorol. Soc. Jpn. 90, 23-64. doi: 10.2151/jmsj.2012-A02

Conflict of Interest: The authors declare that the research was conducted in the absence of any commercial or financial relationships that could be construed as a potential conflict of interest.

Copyright (C) 2019 Sarmiento and Kooperman. This is an open-access article distributed under the terms of the Creative Commons Attribution License (CC BY). The use, distribution or reproduction in other forums is permitted, provided the original author(s) and the copyright owner(s) are credited and that the original publication in this journal is cited, in accordance with accepted academic practice. No use, distribution or reproduction is permitted which does not comply with these terms. 